DOI https://doi.org/10.30525/978-9934-26-073-5-1-42

\title{
ЕВДЕМОНІЗМ ЯК ХУДОЖНІЙ ПРИНЦИП НОВЕЛИ НАТАЛІ РОМАНОВИЧ-ТКАЧЕНКО «НА БАЛКОНІ»
}

\author{
Суворова Л. К. \\ кандидат філологічних наук, \\ викладач украӥнської мови і літератури \\ вищої кваліфікачійної категорії \\ Житомирського базового фармачевтичного фахового коледжу \\ Житомирської обласної ради
}

Храпчук С. Ю.

професійний музикант, письменник

м. Житомир, Украӥна

\begin{abstract}
Основоположник конвенціоналізму - Анрі Пуанкаре - у свій час виголосив ідею немислимого існування логічних протиріч як можливої перешкоди для організації внутрішньої гармонії світу. Будь-яка цінність - відносна, а комбінація цінностей визначає певну життєву рівновагу, механізм якої базується на ідеї «чесности з собою». Його формула полягає у можливості встановлення власного закону нової моралі: погоджености чи непогоджености 3 певними внутрішніми аксіологічними орієнтирами [2, с. $321 ; 1$, с.15], що алюзійно відсилає до принципів так званої евдемоністичної філософії, яка розцінювала щастяблаженство єдиною важливою ціллю життя. Евдемоністичні настрої сформувалися на основі сократівських поглядів: внутрішня свобода особистості можлива за умови самоусвідомленості іiі незалежності від видимого зовнішнього світу. Прагнення до такого стану було художньо прийнятним для прозових текстів письменників епохи модернізму, адже XX століття характеризувалось закоріненням у своїй сутності культу вольової особистості, вивершеної і водночас свідомо зрілої надлюдини, яка поривалась у вимір соціалістичної утопії.

Доволі вдячною у такому інтерпретаційному ключі видається творча спадщина Наталі Романович-Ткаченко. Провідні критики початку XX століття (О. Білецький, М. Свшан, Г. Хоткевич, М. Могилянський, С. Єфремов) частково торкалися літературного обговорення текстів письменниці, проте в подальшому iї прозова і драматургічна творчість фактично не були об'єктом вивчення. Інтерпретація малої прози авторки ставала предметом наукових міркувань сучасних дослідників 162
\end{abstract}


О. Якименко, І. Денисюк, Н. Шумило, В. Агеєвої, Т. Гундорової, Т. Гуляк, проте увагою оминалося прочитання творів у філософському ключі, що скерувало до більш детального простеження евдемоністичного принципу світорозуміння в одній із новел письменниці.

Механізм художнього втілення евдемоністичного способу світосприйняття досягається через звернення авторки до топографічної метафоричної образности, що символічно закладено уже в заголовку новели «На балконі». Балкон постає тим ідилічним локусом, «обжитим простором» (за П. Рікером), відносно обмеженим, замкненим, протилежним згубно-руйнівному світові. Функція зображеного місця дії містить психологічне навантаження; авторка вдається до сюжетного паралелізму, розмежовуючи художній простір на «тут» (балкон, літній вечір, садочок, соловейко) і «там» (Лиса гора, суд, місто; земля, що обливається кров'ю; болото). Така двовимірна локалізація та їі географічні якості презентують читачу протистояння сакрального та профанного світів. Міфопростір балкону (зокрема його просторове розташування) вкотре увиразнює семантику цього локусу як уявного райського світу, входження у який не вимагає від героїв докладання певних зусиль, натомість процес їхнього самоствердження в іншому, ще не освоєному ними соціальному прошарку потребує відречення від власних моральних устоїв. Авторка обрамлює текст семантичними індексами, «іконічними знаками» (кріслогойдалка - знак вагання, нерішучості; самовар - атрибут домашнього релаксу; червоні, сочисті ягоди - символ достатку ціною крові). Кожна деталь у «музеї знаків» (чим можна і вважати локус балкона) презентує оцей видимий предметний простір як гармонійну складну єдність, яка «усвідомлюється як знак цілого» [5, с. 12].

Майновий критерій як означник соціального статусу не знімає проблеми внутрішньої деструктивності, пережитої внаслідок травматичного досвіду - споглядання і неминучої участі у наближенні чужих смертей: «Все се гіпнози - i сі ягоди, i се крісло-гойдалка, i се гарне помешкання <..> Все життя наше живемо ми наче на балконі [6 с. 570; 571]. Рвучкою фразою Лева авторка глобалізує ілюзорність і примарність світу, у якому проживає «щаслива родина». Тогочасна система та її закони рівносильні проходженню ініціального кола: страта людей забезпечить можливість прискорення посвяти у прокурори: «Вели вісім чоловік під конвоєм - на Лису гору, мабуть. Бо вчора ж засудили вісьмох на смерть <.. > Там, знаєш, ми людей вішали. І аж вісім <..> Аж вісім душ за одну хвилину [6, с. 567; 569]. Образ смерти у новелі асоціюється із безоднею, яка поглинає життя, i водночас активізує відчуття страху перед неминучістю. Слушним видається зауваження 
Я. Поліщука: «Страх руйнує раціональний уклад життя, цілком зненацька застає певних себе героїв, оприявнюючи в їхній душі щось таємне, незбагненне, підсвідоме» [3, с. 112].

Евдемонізм як принцип оприявнення моральних цінностей увиразнюється через відтворення письменницею опису літнього відпочинку родини, у колі якої ведуться розмови про високі духовні ідеали, які, на їхню думку, формують каркас щасливої дійсності. Кожен з героїв асоціативно нанизуе на концепт щастя власні ключові домінанти. Авторка пропонує властиве для тогочасної прози заглиблення в інтимний світ жінки, порушення проблем материнства, життєвих цінностей, протистояння у ній чуттєвого та раціонального. Інтерпретація жіночого психотипу прочитується у двох окремих лінійних проєкціях - дочки i матері, кожна $з$ яких бачить «гендерну конфронтацію» (А. Швець) у вкрай протилежних ракурсах. Через образ Ганнусі Н. РомановичТкаченко висловлює заперечення емансипаційних поглядів. Ганна уособлює традиційний тип жінки - вразливої, з виразним материнським самовиявом, самозреченністю. Натомість іiі матір вважає, що жіноча функція не зводиться лише до виховання дітей та створення сімейного затишку. Така видима колізія стосунків обох жінок рухає сюжет твору і водночас позиціонує читачу психологію жіночих цінностей. Жертовна упокореність материнству як «цілковитому відданню себе дитині» не сприймається героїнею як дефект, що перешкоджатиме проживанню щастя. Моральний компроміс щодо материнської жертовності між Ганною та ії матір'ю поступово витісняється розмовою про «корисність» кожної особистості, заданість якої формує запоруку щасливого життя. Виховання матір'ю дитини розцінюється нею як поступовий процес «створення людини», формування у ній якостей самопіднесення і самодосконалості. Природний закон підтримання роду, визначення інстинкту дітонародження як фундаментального, а материнства як провідної соціальної ролі на рівні підсвідомості зароджує внутрішню полеміку між системою усталених моральних цінностей і намаганням реалізувати свій потенціал.

Чоловіча аксіологічна призма, втілена в образі Лева, виходить за рамки родинного кола і мислиться більш масштабно. Мікросвіт його екзистенційного буття розділяють два амбівалентні топоси - рідний дім (балкон як уособлення раю) і Лиса гора (Голгофа смерті). Лев усвідомлює зраду сердечним, людським почуттям перед корисливістю «зручної» життєвої влаштованості, тому проживає стан душевного розпачу, внутрішнього роздвоєння між власною сім'єю, можливістю іiі матеріального забезпеченням і соціальним обов'язком, який передбачав 
можливість проживання ілюзорного «щастя» ціною чужих життів. «Ефект психологічної достовірності» [7, с. 430] запускає в Ганні «рефлексійний струмінь», що обриває на мить материнське чуття (жінка навіть не звертає уваги на дитячий плач) і змушує іiі вийти за межі власних інстинктивних кордонів: через оприявлення такої фемінності виникає роздвоєність між соціальним і власне материнським [4, с. 141]. За міркуваннями Левка, досягнення щастя можливе тільки через проходження акту самозречення: «покинути се все й піти з балкона... драбинка така $\epsilon . .$. I щаблі іiі: віра, любов, праця, відвага...» [6, с. 572]. Домінування у ньому раціонального начала як невіддільної умови організації гармонійної життєдіяльності увиразнено запуском механізму душевних рецепторів. Внутрішня роздвоєність Левка додатково посилюється відчуттям страху, яке формується через розцінювання життя як «загіпнотизованого привабливістю» [6, с. 572] існування: теперішне сприймається героєм як тимчасове уявне. Психологічні коливання персонажів, внутрішньособисті конфлікти та аксіологічна роздвоєність перешкоджають прийняттю виваженого рішення, яке ілюструвало б його ціннісну еволюцію, здатну задати звучання, ідентичного абсолютному евдемоністичному станові.

\section{Лiтература:}

1. Винниченко В. Щастя. Листи до юнака, од. 39, ч. 4 - 2. С. 15.

2. Гундорова Т. ПроЯвлення Слова. Дискурсія раннього українського модернізму. К.: Критика, 2009. 448 с.

3. Поліщук Я. І ката, і героя він любив...: Літературний портрет. К.: Академія, 2010. 304 с.

4. Психология личности: словарь-справочник. Под ред. П. Горностая, Т. Титаренко. Киев: Рута, 2001. С. 141.

5. Ревзина О. Память и язык. Критика и семиотика. 2006, Вып. 10. С. 10-24.

6. Українська новелістика кінця XIX поч. XX ст. Оповідання. Новели. Фрагментарні форми (ескізи, етюди, нариси, образки, поезії в прозі). Упоряд. і прим. Є.. Нахліка; вступ. ст. І. Денисюка. К.: Наук. думка, 1989. $688 \mathrm{c}$.

7. Швець А. Жінка 3 хистом Аріадни: Життєвий світ Наталії Кобринської в генераційному, світоглядному і творчому вимірах: монографія. Львів, 2018. 752 с.

8. Якименко О. Поетика творчості Наталі Романович-Ткаченко: дис. на здобуття наук. ступеня канд. філ. наук : 10.01.01. Київ, 2013. 196 с. 